\title{
Foraging performance and reproductive success of Humboldt penguins in relation to prey availability
}

\author{
J. C. Hennicke ${ }^{1, *}$, B. M. Culik ${ }^{2}$ \\ ${ }^{1}$ Zoologisches Institut und Museum, Universität Hamburg, Martin-Luther-King-Platz 37, 20146 Hamburg, Germany \\ ${ }^{2}$ Institut für Meereskunde, Düsternbrooker Weg 20, 24105 Kiel, Germany
}

\begin{abstract}
During the austral summer 1998/1999, we compared foraging ecology and reproduction between chick-rearing Humboldt penguins Spheniscus humboldti at 2 colonies in Chile. At Pan de Azúcar in northern Chile prey availability was assumed to be lower than at Puñihuil, $1500 \mathrm{~km}$ further south, according to oceanographic data. Fifteen adult penguins were equipped with temperaturedepth recorders and stomach-temperature-loggers in order to investigate foraging effort and foraging success in relation to differences in prey availability. There were no differences between colonies in diving behaviour. At Pan de Azúcar, foraging trips were longer than at Puñihuil (mean duration $36.5 \pm 7.8 \mathrm{~h}$ vs. $19.0 \pm 8.7 \mathrm{~h}$ ), resulting in higher energy expenditure per foraging trip (on average $8092.7 \pm 2216.7 \mathrm{~kJ}$ vs. $3934.5 \mathrm{~kJ}$, range: 3071 to $7930 \mathrm{~kJ}$ ). Catch per unit effort at Pan de Azúcar equalled $2.2 \pm 1.4 \mathrm{~g} \mathrm{~min}^{-1}$ under water, which was significantly less than $10.0 \pm 7.3 \mathrm{~g} \mathrm{~min}^{-1}$ at Puñihuil. As a result of higher energetic costs and lower foraging success, the gross foraging efficiency per foraging trip (GFE) was lower at Pan de Azúcar than at Puñihuil (on average $0.94 \pm 0.52$ vs. 4.61 $\pm 3.4\left[\mathrm{~kJ}\right.$ gained/kJ invested]). The chick growth rates at Pan de Azúcar (mass: $40.0 \pm 18.4 \mathrm{~g} \mathrm{~d}^{-1} \mathrm{vs}$. $63.0 \pm 23.0 \mathrm{~g} \mathrm{~d}^{-1}$; bill length: $0.32 \pm 0.07 \mathrm{~mm} \mathrm{~d}^{-1}$ vs. $\left.0.47 \pm 0.12 \mathrm{~mm} \mathrm{~d}^{-1}\right)$, as well as chick survival $(40 \%$ vs. $100 \%$ ) and reproductive success ( 0.33 vs. 0.81 fledglings nest $\left.^{-1}\right)$, were lower compared to Puñihuil. A GFE threshold of 1.08 was calculated for chick survival at Pan de Azúcar. We conclude that due to physiological and morphological constraints the penguins at Pan de Azúcar could not increase diving effort to compensate for lower prey availability, but took extended foraging trips instead. Therefore, foraging efficiency and meal delivery rate decreased, resulting in less chick growth and lower reproductive success.
\end{abstract}

KEY WORDS: Gross foraging efficiency $\cdot$ Humboldt penguin $\cdot$ Diving behaviour $\cdot$ Foraging trip duration $\cdot$ CPUE $\cdot$ Reproductive success

Resale or republication not permitted without written consent of the publisher

\section{INTRODUCTION}

Seabirds have to cope with a heterogeneous environment. At sea, prey abundance and availability vary considerably on a temporal and spatial scale influenced by a variety of biotic and abiotic parameters (Hunt \& Schneider 1987). To forage successfully, seabirds have to adjust their foraging behaviour to the given prey availability (Morrison et al. 1990). As foraging behaviour and reproduction are, to some extent, interrelated (Furness \& Monaghan 1987, Schreiber \& Burger 2001), any alteration of foraging parameters might have an impact on the reproductive performance of the animal.
Humboldt penguins Spheniscus humboldti are ideally suited to investigate adjustments in foraging behaviour and its consequences. In its distributional range of $>4500 \mathrm{~km}$ along the west coast of South America, the species is exposed to a large variety of different ecological parameters (Williams 1995). Some colonies experience the nutrient-rich upwelling of the Humboldt current, while others lie outside the influence of this system (Lalli \& Parsons 1997, Colling 2001). Moreover, the ocean-atmosphere-coupled phenomenon El Niño Southern Oscillation (ENSO), occurring every 4 to 12 yr (Quinn et al. 1978), causes fundamental ecological changes, especially in the northern parts of the habitat of the Humboldt penguins (Arntz \& 
Fahrbach 1991). These changes also affect the abundance and availability of prey species (Arntz \& Fahrbach 1991, Arntz et al. 1991). To survive and to breed under such variable ecological conditions, Humboldt penguins should be able to adjust their foraging behaviour to the different oceanographic conditions of their habitat (Culik et al. 2000, Culik 2001).

Several studies have investigated variations in the foraging behaviour of penguins. Foraging characteristics vary, e.g. according to light levels (Wilson et al. 1993), presence of sea-ice (Watanuki et al. 1997), prey species and availability (Croxall et al. 1988, Watanuki et al. 1993), breeding stage and energy demands (Charrassin et al. 1998). However, none of these studies examined the underlying energetics of the behavioural adjustments to varying ecological parameters, nor did they determine quantitative relationships between foraging effort, foraging success and reproduction. This knowledge, however, is important for gaining insight into functional aspects of foraging and reproductive strategies in seabirds.

In the present study, we compared the foraging behaviour and the reproductive output of Humboldt penguins between 2 colonies bordering areas with different oceanographic conditions. We aimed to investigate (1) if and how Humboldt penguins adjust their foraging effort to prey availability, (2) how an adjustment affects the foraging success and the foraging energetics, and (3) what consequences an adjustment has for the reproductive performance of the penguins.

\section{MATERIALS AND METHODS}

Study areas and oceanographic conditions. Field work was conducted at 2 breeding colonies of Humboldt penguins in Chile in the austral summer 1998/1999: at Pan de Azúcar Island $\left(26^{\circ} 09^{\prime} \mathrm{S}\right.$, $70^{\circ} 41^{\prime}$ W), Pan de Azúcar National Park in northern Chile, and, $1500 \mathrm{~km}$ further south, at the Puñihuil colony $\left(41^{\circ} 55^{\prime} \mathrm{S}, 74^{\circ} 02^{\prime} \mathrm{W}\right)$, Chiloe Island in southern central Chile. Along the distributional range of the species, the start of the breeding season is delayed from north to south (Williams 1995). At Pan de Azúcar, the breeding season begins in October, whereas, at Puñihuil, breeding commences in December. This made it possible to conduct the study in 2 distant colonies during the breeding peaks of the same season. At Pan de Azúcar, the investigations took place from 17 October to 23 November 1998; at Puñihuil, work was conducted from 8 January to 2 March 1999.

At Pan de Azúcar Island, cold, nutrient-rich surface water is maintained by the Humboldt current flowing northwards from Antarctica (Lalli \& Parsons 1997, Colling 2001). The island is one of the most important breeding colonies of Humboldt penguins in northern Chile (Luna-Jorquera 1996), with about 800 breeding birds counted during the field season 1998/1999 (J. C. Hennicke unpubl. data).

The marine area of the Puñihuil colony is not influenced by the upwelling of the Humboldt current (Lalli \& Parsons 1997). Nutrients are mainly transported into the ocean by various rivers. Puñihuil is the southernmost breeding colony of Humboldt penguins (Williams 1995) and the only known mixed colony of Humboldt and Magellanic penguins Spheniscus magellanicus in the world (Simeone \& Schlatter 1998). In the study year, approximately 150 Humboldt and 500 Magellanic penguins were counted breeding on the island ( $\mathrm{J}$. C. Hennicke unpubl. data).

During the study period, oceanographic conditions differed at the colonies. At Pan de Azúcar, oceanographic conditions were potentially still influenced by the strong El Niño that hit the west coast of northern South America the previous austral summer (Kerr 1999, McPhaden 1999a,b), as sea-surface temperature was still slightly increased $\left(+0.31^{\circ} \mathrm{C}\right.$, data provided by the Chilean Navy) and about $60 \%$ fewer fish were caught compared to the non-El Niño year 1996 (SERNAP 1997, 1999). At this colony, average sea-surface temperatures were higher, and chlorophyll a concentrations, a proxy for the marine productivity (Ryther 1969), were lower than at Puñihuil $\left(15.8^{\circ} \mathrm{C}\right.$ and $0.48 \mathrm{mg} \mathrm{m}^{-3}$ vs. $14.5^{\circ} \mathrm{C}$ and $2.72 \mathrm{mg} \mathrm{m}^{-3}$, respectively; data compiled from International Research Institute for Climate Prediction by T. Martin, Institut für Meereskunde, Kiel, Germany, and calculated for a marine area $1^{\circ}$ west and $0.5^{\circ}$ north and south of each colony). Given these differences, prey abundance and availability were assumed to be lower at Pan de Azúcar.

Devices. The birds were equipped with time-depth recorders (TDR; Mk5 and Mk6, Wildlife Computers) to monitor diving behaviour. In order to reduce drag, the devices were hydrodynamically shaped by attaching tapered 'noses' at the front of the devices, following Bannasch et al. (1994). The Mk5 weighed $81 \mathrm{~g}$ in total ( $2 \%$ of adult mass), with maximum dimensions of $98 \times$ $42 \times 21 \mathrm{~mm}$ (length $\times$ width $\times$ height), while the Mk6 weighed $115 \mathrm{~g} \mathrm{(} \mathrm{2.9 \%} \mathrm{of} \mathrm{adult} \mathrm{mass),} \mathrm{with} \mathrm{maximum}$ dimensions of $118 \times 59 \times 37 \mathrm{~mm}$. The pressure resolution was 0.3 (Mk5) and $0.5 \mathrm{~m}$ (Mk6), and the temperature resolution was $0.1^{\circ} \mathrm{C}$ in both devices. Mk6 loggers had a frontal paddle wheel to measure swimming velocity. Animals carrying Mk5 loggers were attributed a swimming velocity calculated by averaging the velocities of the birds equipped with Mk6 loggers. All devices were attached onto penguin backs with Tesa tape, following Wilson et al. (1997). The sampling interval was set to $2 \mathrm{~s}$ for pressure and velocity. 
In addition, all birds were induced to swallow a stomach-temperature logger (STL) to record feeding events (Wilson et al. 1995b). The device was a DK-Log 120 temperature logger (Driesen und Kern) in a Titanium housing (98 $\mathrm{mm}$ long, with a diameter of $16 \mathrm{~mm}$ ). The total weight was $32 \mathrm{~g}$. A spring crown was attached at the bottom of the housing to reduce the probability of the logger being regurgitated (Wilson et al. 1998). At the top of the housing, a magnet was attached. For retrieval of the STL, a silicon tube with a magnet at the end was introduced through the bird's throat into the stomach. After the magnets attached to each other, the STL could easily be pulled out of the penguin. The temperature resolution was measured to $0.1^{\circ} \mathrm{C}$, and temperature was logged every $8 \mathrm{~s}$.

Study animals were caught on the nest with a noose pole. All birds had 2 chicks of 2 to $5 \mathrm{wk}$ of age. Adults were weighed to check for potential mass dependence of dive parameters and to calculate energy expenditure during foraging (see subsection 'Foraging energetics'). For attachment and retrieval of the devices, the animals were sedated (see Luna-Jorquera et al. 1996 for details). Attachment time was approximately $30 \mathrm{~min}$, after which the animals were put back on the nest where they awoke from sedation. Birds were recaptured after 3 to $18 \mathrm{~d}$, and loggers were removed. Removal took approximately $20 \mathrm{~min}$. Data were then downloaded onto a laptop computer for further analysis.

Reproductive performance. Reproductive success and chick survival were monitored by checking nests of breeding penguins for eggs, chicks and fledglings at intervals of 8 to $11 \mathrm{~d}$. When only 1 chick or egg was found in the nest at the start of the field season, 2 eggs nest ${ }^{-1}$ were assumed to have been laid originally (see Zavalaga \& Paredes 1997). To determine growth rates, chicks were weighed repeatedly at intervals of 8 to $11 \mathrm{~d}$ with spring balances to $5 \mathrm{~g}$ precision and bill length was measured with callipers to $0.01 \mathrm{~mm}$ precision.

In order to investigate the impact of the study on the survival of the penguin chicks, a control experiment was conducted at Pan de Azúcar. Out of all the nests at the colony found with 2 chicks in them, 10 and 11 nests were randomly assigned to a control group and an experimental group, respectively. In the control group, the survival of the chicks was followed only by visual inspection from a distance, no measurements were taken on the chicks or the adults, and the adults were not equipped with any devices. In the experimental group, chicks were regularly weighed and measured, and adults of some nests were equipped with loggers.

Analysis. Logger data: Data on the diving behaviour were analysed using ANDIVE 8.0 (Jensen Software Systems). Diving thresholds were 0.3 and $0.5 \mathrm{~m}$ for Mk5 and Mk6 loggers, respectively. Dives up to $3 \mathrm{~m}$ were defined as travelling dives, and dives deeper than $3 \mathrm{~m}$ as foraging dives (LunaJorquera \& Culik 1999, Radl \& Culik 1999). Unless specifically stated, the results refer only to foraging dives, as these are more relevant to overall foraging performance than travelling dives.

Some animals stayed at sea during the night, when only little or no foraging activity took place, as penguins are visual hunters (Williams 1995). Therefore, parameters of foraging activity depending on light levels (e.g. diving activity, number of dives per hour foraging trip) were calculated using a corrected time at sea value (TAScorr), subtracting the hours of darkness from the total time at sea. Average periods of darkness were $8.9 \mathrm{~h}$ at Pan de Azúcar and $7.6 \mathrm{~h}$ at Puñihuil.

Physiological dive efficiency was calculated for foraging dives using a modified formula from Ydenberg \& Clark (1998): dive efficiency = dive duration/dive cycle duration. The duration of a dive cycle equals the time period from the start of a dive to the start of the subsequent dive; thus, it includes dive duration and postdive surface time.

Stomach temperature data were analysed using FEEDINT 3.0 (Jensen Software Systems). Feeding events were determined following Grémillet \& Plös (1994) and Wilson et al. (1995b), and integrals for their magnitudes were calculated using the formulas of Wilson et al. (1995b). For time periods in which event detection became unreliable, e.g. due to stomach filling (Grémillet \& Plös 1994) or downregulated stomach temperature (Peters 1997), we extrapolated feeding activity from periods prior to the unreliable period. These periods occurred mainly at the end of the foraging trip, and they were characterised by a constant decrease in integral size after frequent prey ingestions or in stomach temperature despite bird activity. For determining prey mass, stomach samples were taken at both colonies by water off-loading (Wilson 1984). For each colony separately, the mass distribution of prey items was matched with the distribution of integrals of single prey item feeding events. The ratio of the medians of the 2 distributions was then used as a factor for converting event size into prey mass. Catch per unit effort (CPUE) was defined as the mass of prey caught per minute under water.

Foraging energetics: Gross foraging efficiency of a foraging trip (GFE) was defined as the energy gained during the foraging trip divided by the energy spent (Weathers \& Sulivan 1991). From stomach samples (see above), prey composition (relative contribution to the total wet biomass of fish, cephalopods and crustaceans) and the energy content of fish were determined. At both colonies, prey consisted mainly of coldwater shoaling fish such as anchovies Engraulis ringens, sardines Sardinops sagax and garfish Scomberesox saurus (Herling et al. 2005). At Pan de 
Azúcar, prey composition was 96.4:3.5:0.1 (\% fish: cephalopods:crustaceans); at Puñihuil, the ratio was 67.0:22.2:10.8. The average energy content of fish was $6.7 \mathrm{~kJ} \mathrm{~g}^{-1}$ at Pan de Azúcar and $5.5 \mathrm{~kJ} \mathrm{~g}^{-1}$ at Puñihuil, determined by calorimetry (for details see Herling 2001, Herling et al. 2005). Energy contents of cephalopods and crustaceans were 3.5 and $4.0 \mathrm{~kJ} \mathrm{~g}^{-1}$, respectively (Tasker \& Furness 1996). The assimilation coefficient for fish was 0.773 (Guerra 1992); for cephalopods and crustaceans it was 0.7 (Tasker \& Furness 1996). This calculated to an average energy value for the diet at Pan de Azúcar of $4.3 \mathrm{~kJ} \mathrm{~g}^{-1}$ and at Puñihuil of $4.2 \mathrm{~kJ}$ $\mathrm{g}^{-1}$. These values were multiplied by the prey mass the penguin ingested during its foraging trip, resulting in the energy gain of this individual. The energy spent was calculated adapting the calculations of LunaJorquera \& Culik (2000) to the current study. For GFE calculation, only birds with complete data sets of both TDRs and STLs were used.

Reproductive performance: Due to the 8 to $11 \mathrm{~d}$ intervals between nest visits, it was not possible to determine precise hatching dates of chicks. Therefore, no age-dependent growth curves could be generated for comparison between colonies. Instead, we formed chick pairs (1 chick from each colony), in which the chicks had the same weight or bill length at a given measuring occasion. For each chick of a pair, the daily increase of mass or bill length till the subsequent measuring was calculated. The differences in growth rates could then be compared between colonies by a paired testing of the increase per day in mass and bill length within each chick pair. Each chick was included in the analysis only once, and it was taken into account whether the nest contained 2 chicks or only 1 chick.

Statistics: Prior to the application of statistical tests, all data were tested for normality. Due to significant differences in normality within and heteroscedasticity between data sets of individual birds, mean or median values were determined for each individual and, when appropriate, used to calculate overall averages or to compare colonies. At both colonies, there was significant correlation between dive depth and dive duration; therefore, only mean dive duration and maximum dive depth per foraging trip were compared statistically between colonies (Pan de Azúcar: $\mathrm{r}_{\mathrm{s}}=0.646, \mathrm{p}<0.01$, $\mathrm{n}=4699$; Puñihuil: $\left.\mathrm{r}_{\mathrm{s}}=0.806, \mathrm{p}<0.01, \mathrm{n}=4445\right)$. All statistical tests were 2 -tailed.

\section{RESULTS}

\section{Foraging behaviour}

At Pan de Azúcar, 9 breeding Humboldt penguins Spheniscus humboldti were equipped with TDRs and
STLs; 3 animals lost both devices. Complete data sets of both loggers could be retrieved from 6 birds. In total, $219.0 \mathrm{~h}$ worth of data at sea were collected encompassing 1484 travelling dives, 4699 foraging dives and 308 feeding events.

At Puñihuil, 11 breeding penguins were equipped with TDRs and STLs. From 9 animals the loggers could be recovered; 2 birds lost both devices. All 9 TDRs, but only 6 STLs, had complete data sets on the foraging trips, as in the 3 STLs data recording failed. In total, data on $170.6 \mathrm{~h}$ at sea were gathered, yielding 1926 travelling dives and 4445 foraging dives of 9 birds, as well as 155 feeding events of 6 birds.

There was no significant difference between colonies in weight or bill length of the study animals (weight: $t_{13.0}=0.85, \mathrm{p}>0.05, \mathrm{n}=15$; bill length: $t_{11.4}=$ $0.66, \mathrm{p}>0.05, \mathrm{n}=15$ ).

\section{Time at sea}

At Pan de Azúcar, the foraging trips had a mean duration of $36.5 \pm 7.8 \mathrm{~h}$. All birds spent at least part of the night out at sea, 2 birds spent 2 nights at sea. The corrected time at sea had a median of $27.3 \mathrm{~h}$ (range 14.3 to 29.6 h). At Puñihuil, foraging trips were shorter, and only 4 of the birds spent time at sea at night. The mean duration of a foraging trip was $19.0 \pm 8.7 \mathrm{~h}$, the median of the corrected time at sea was $13.7 \mathrm{~h}$ (range 10.4 to $30.1 \mathrm{~h}$ ). The differences between colonies were significant (TAS, Fig. 1A: $t_{13.0}=3.97, \mathrm{p}<0.05, \mathrm{n}=15$; TAScorr, $U=8.0, \mathrm{p}<0.05, \mathrm{n}=15$ ).

\section{Diving}

No differences in diving behaviour could be detected between colonies: dive duration, maximum dive depth, swimming speed, time under water foraging and travelling, dives per hour and diving efficiency were not significantly different between Pan de Azúcar and Puñihuil (Table 1).

\section{Foraging energetics}

At Pan de Azúcar, the birds caught on average $1879.9 \pm 1070.8 \mathrm{~g}$ of prey during their foraging trips, which resulted in an energy gain of $8083.7 \pm 4604.3 \mathrm{~kJ}$ trip $^{-1}$. This was not significantly different from the $4420.5 \pm 3413.4 \mathrm{~g} \mathrm{trip}^{-1}$ and $18566.0 \pm 14336.1 \mathrm{~kJ}$ trip $^{-1}$ at Puñihuil (wet mass: $t_{6.0}=1.7, \mathrm{p}>0.05, \mathrm{n}=12$; caloric value: $t_{6.0}=1.7, \mathrm{p}>0.05, \mathrm{n}=12$ ) (Table 1 ).

CPUE was significantly lower at Pan de Azúcar $\left(t_{5.4}=2.6, \mathrm{p}<0.05, \mathrm{n}=12\right)$. At this colony, the mean 
CPUE was $2.2 \pm 1.4 \mathrm{~g} \mathrm{~min}^{-1}$, while at Puñihuil more prey was caught, with $10.0 \pm 7.3 \mathrm{~g} \mathrm{~min}^{-1}$ (Fig. 1B, Table 1).
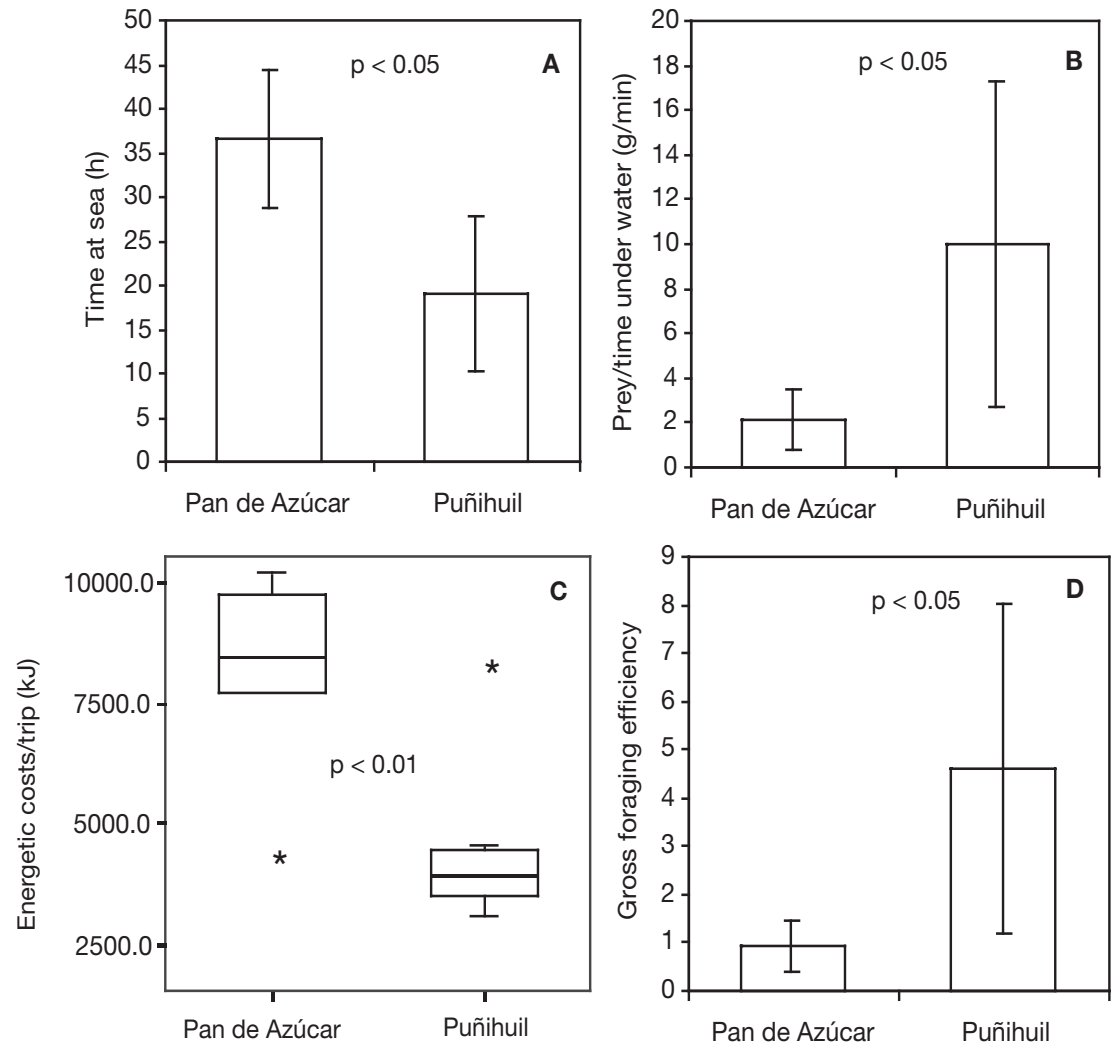

Fig. 1. Spheniscus humboldti. Selection of parameters compared between Pan de Azúcar and Puñihuil: (A) time at sea; (B) catch per unit effort; (C) energy cost per foraging trip; (D) gross foraging efficiency. In (A), (B), and (D): means (box) with standard deviations; in (C): median (thick line), $25 \%$ and $75 \%$ interquartiles (box), range (whiskers) with outliers (*)
The energetic costs per trip differed significantly between colonies $(U=5.0, \mathrm{p}<0.01, \mathrm{n}=15)$. At Pan de Azúcar, the mean energetic costs were 8092.7 \pm $2216.7 \mathrm{~kJ}$ trip $^{-1}$. At Puñihuil, trips were less costly, with a median of $3934.5 \mathrm{~kJ}$ trip $^{-1}$ (range 3070.6 to 7930.2) (Fig. 1C). The energetic costs per trip-hour were not significantly different between colonies (TAS, $t_{13.0}$ $=0.9, \mathrm{p}>0.05, \mathrm{n}=15)$. At Pan de Azúcar, the penguins spent $218.9 \pm 28.6 \mathrm{~kJ}$ $\mathrm{h}^{-1}$ TAS; at Puñihuil, they spent 244.6 $\pm 58.9 \mathrm{~kJ} \mathrm{~h}^{-1}$ TAS (Table 1).

Energetic gain and costs yielded a gross foraging efficiency per foraging trip that was significantly lower at Pan de Azúcar ( $t_{5.2}=2.6, \mathrm{p}<0.05, \mathrm{n}=12$ ). At this colony, the mean GFE was $0.94 \pm 0.52$, whereas at Puñihuil it was $4.61 \pm 3.4$ (Fig. 1D, Table 1).

\section{Reproductive performance}

Reproductive success

Reproductive success was examined in 30 and 48 nests at Pan de Azúcar and Puñihuil, respectively. At Pan de Azúcar, out of 25 hatched chicks, 10 $(40 \%)$ survived to fledging, while at Puñihuil, all 39 hatched chicks survived and fledged. Chick survival was significantly higher at Puñihuil (Fisher's test, $\mathrm{p}<0.001, \mathrm{n}=64$ ).

Table 1. Spheniscus humboldti. Statistics of the parameters on foraging behaviour compared between Pan de Azúcar and Puñihuil (means given with standard deviations, medians in italics with ranges) (TAScorr: corrected time at sea value)

\begin{tabular}{|c|c|c|c|c|c|c|c|}
\hline & \multicolumn{3}{|c|}{ Pan de Azúcar } & \multicolumn{3}{|c|}{ Puñihuil } & \multirow[t]{2}{*}{$\mathrm{p}$} \\
\hline & $\mathrm{n}$ & Mean/Median & SD/Range & $\mathrm{n}$ & Mean/Median & SD/Range & \\
\hline Time at sea (TAS) (h) & 6 & 36.5 & \pm 7.8 & 9 & 19.0 & \pm 8.7 & $<0.05$ \\
\hline TAScorr (h) & 6 & 27.3 & $14.3-29.6$ & 9 & 13.7 & $10.4-30.1$ & $<0.05$ \\
\hline Dives per hour & 6 & 31.6 & \pm 5.2 & 9 & 30.7 & \pm 8.1 & $\mathrm{~ns}$ \\
\hline Max. dive depth (m) & 6 & 39.2 & \pm 8.1 & 9 & 43.0 & \pm 13.1 & ns \\
\hline Dive duration (s) & 6 & 62 & \pm 9.5 & 9 & 59 & \pm 11.5 & ns \\
\hline Diving activity (travel) (\%) & 6 & 0.03 & \pm 0.02 & 9 & 0.04 & \pm 0.02 & ns \\
\hline Diving activity (foraging) (\%) & 6 & 0.51 & \pm 0.04 & 9 & 0.49 & \pm 0.1 & ns \\
\hline Diving efficiency & 6 & 0.75 & $0.71-0.77$ & 9 & 0.74 & \pm 0.04 & ns \\
\hline Swimming speed, travelling $\left(\mathrm{m} \mathrm{s}^{-1}\right)$ & 5 & 1.8 & \pm 0.02 & 9 & 1.9 & \pm 0.03 & ns \\
\hline Swimming speed, foraging $\left(\mathrm{m} \mathrm{s}^{-1}\right)$ & 5 & 2.0 & \pm 0.06 & 9 & 1.9 & $1.9-2.1$ & ns \\
\hline Catch per unit effort ( $\mathrm{g} \mathrm{min}^{-1}$ under water) & 6 & 2.2 & \pm 1.4 & 6 & 10.0 & \pm 7.3 & $<0.05$ \\
\hline Prey per trip (g) & 6 & 1879.9 & \pm 1070.8 & 6 & 4420.5 & \pm 3413.4 & ns \\
\hline Energy gain per trip (kJ) & 6 & 8083.7 & \pm 4604.3 & 6 & 18566.1 & \pm 14336.1 & ns \\
\hline Energy costs per hour (kJ) & 6 & 218.9 & \pm 28.6 & 9 & 244.6 & \pm 58.9 & ns \\
\hline Energy costs per trip $(\mathrm{kJ})$ & 6 & 8092.7 & \pm 2216.7 & 9 & 3934.5 & $3071-7930$ & $<0.01$ \\
\hline Gross foraging efficiency & 6 & 0.94 & \pm 0.52 & 6 & 4.61 & \pm 3.4 & $<0.05$ \\
\hline
\end{tabular}


At Pan de Azúcar, 10 chicks fledged in the 30 nests, which equals 0.33 fledglings nest ${ }^{-1}$. At Puñihuil, there were 39 fledglings in 48 nests, or 0.81 fledglings nest $^{-1}$; this was significantly higher than at Pan de Azúcar $\left(\chi_{1}^{2}=8.76, \mathrm{p}<0.05, \mathrm{n}=156\right)$.

\section{Growth rates}

For growth rates, at least 2 measurements of 73 chicks from 41 nests at Pan de Azúcar and of 33 chicks from 22 nests at Puñihuil were taken. This resulted in 12 comparisons between colonies on mass gain, and 15 on bill length.

The chicks at Pan de Azúcar gained on average $40.0 \pm 18.4 \mathrm{~g} \mathrm{~d}^{-1}$, and their bills grew by $0.32 \pm 0.07 \mathrm{~mm}$ $\mathrm{d}^{-1}$. At Puñihuil, the chicks' mass increased by $63.0 \pm$ $23.0 \mathrm{~g} \mathrm{~d}^{-1}$, and bill length by $0.47 \pm 0.12 \mathrm{~mm} \mathrm{~d}^{-1}$. Both parameters differed significantly between colonies (mass: $t_{11.0}=-2.6, \mathrm{p}<0.05, \mathrm{n}=12$; bill length: $t_{14.0}=$ $-4.1, \mathrm{p}<0.05, \mathrm{n}=15)$.

Impact of investigations on chick survival

In the experimental group, 6 of the 22 chicks fledged; 8 nests were abandoned and all of those chicks died. In the 3 remaining nests, both chicks survived and fledged. In the control group, 6 of the 20 chicks survived to fledging in 3 nests. The other 7 nests were abandoned and all of those chicks died. There was no significant difference in chick survival between groups (Fisher's test, $\mathrm{p}>0.05, \mathrm{n}=32$ ).

\section{DISCUSSION}

\section{Impact of the study}

In the experiment on the impact of the investigation on chick survival in Humboldt penguins Spheniscus humboldti, no difference between the untreated control group and the experimental group was found. A negative effect of the study on chick survival can therefore be ruled out.

STLs have never been used in Humboldt penguins before. STLs similar to the ones of the current study, however, have been used in studies on other seabirds, including penguins, and no negative effects on adults or chicks were observed (Grémillet \& Plös 1994, Peters 1997, Garthe et al. 1999).

Externally attached devices are known to affect penguins, as found in various studies (Culik \& Wilson 1991a,b, Bannasch et al. 1994, Culik et al. 1994a,b, Luna-Jorquera \& Culik 2000, Taylor et al. 2001, Rop-
ert-Coudert et al. 2000). Yet, Luna-Jorquera (1996) did not observe any effects of loggers similar to the ones in the current study on trip duration, bird weight, or reproductive success in his study on Humboldt penguins. It is possible that our birds were affected in other foraging parameters, but, as at both colonies the same devices were used, any potential impact is assumed to have been similar at both sites and unlikely to have influenced the qualitative relationships and overall results of the study.

\section{Foraging behaviour and its adjustment to prey availability}

The penguins from the 2 colonies foraged in a similar manner. There were no significant differences in diving behaviour. Foraging trips, however, were significantly longer at Pan de Azúcar (36.5 h) compared to Puñihuil $(19.0 \mathrm{~h})$, although at both colonies penguins foraged close to the island (J. C. Hennicke unpubl. data). When corrected for the night period (see 'Materials and methods'), trips at Pan de Azúcar were still significantly longer than at Puñihuil (27.3 vs. 13.7 h).

Moreover, CPUE at Pan de Azúcar was significantly lower than at Puñihuil. Penguins caught only $2.2 \mathrm{~g}$ min $^{-1}$ under water, which was about 4 times less than at Puñihuil, with $10.0 \mathrm{~g} \mathrm{~min}^{-1}$. CPUE is determined by the behaviour of the foraging bird (effort) and prey availability. Since at both colonies the birds showed similar foraging behaviour, the difference in CPUE is likely to have been caused by lower prey availability at Pan de Azúcar.

Prey availability depends on a variety of factors such as prey species, competition, or prey abundance (see Schreiber \& Burger 2001 for an overview). At both study sites, penguins hunted similar prey, mainly coldwater shoaling fish (see 'Materials and methods'). Competition was also similar between colonies. First, the number of competing penguins was comparable at both sites, with about 800 animals at Pan de Azúcar and approximately 150 Humboldt penguins and 550 Magellanic penguins at Puñihuil. As both species are similar in morphology and foraging ecology (Williams 1995), one species out-competing the other is unlikely (see also Wilson et al. 1995a). Second, differences in competition with, e.g., seals, cormorants, or gulls is also improbable, as species composition at both study sites was similar. Therefore, it is likely that the lower prey availability at Pan de Azúcar was caused by a lower prey abundance. This matches the higher water temperature, the lower chlorophyll a concentration, and the reduced catches by fishery at this study site.

In order to maximise foraging efficiency, a penguin should adjust its foraging behaviour to a given prey 
availability. When prey abundance is low, the larger the water body the penguin covers during diving, the higher the probability to encounter prey (Wilson 1995). To increase the searched water body, penguins can either swim faster or spend more time under water. However, there were no differences in swimming velocities, dive durations, or diving activity per triphour between the 2 colonies, only foraging trips were longer at Pan de Azúcar. Thus, the observed diving behaviour seems to be optimal under both prey conditions. As diving efficiency in penguins is mainly determined by morphology and physiology (Kooyman 1989, Schmitt-Nielsen 1990, Wilson 1995), it seems likely that the penguins at Pan de Azúcar could not increase their diving effort due to morphological and physiological constraints. Instead, the birds increased the duration of their foraging trips to compensate lower prey availability.

\section{Foraging energetics}

Energetic costs per hour foraging trip were not significantly different between colonies. The longer foraging trips at Pan de Azúcar, however, increased the total energetic costs per foraging trip to $8092.7 \mathrm{~kJ}$ trip $^{-1}$, more than twice that at Puñihuil, with $3924.5 \mathrm{~kJ}$ trip $^{-1}$.

By extending their foraging trips, the penguins at Pan de Azúcar tried to compensate for low prey availability. Yet, they succeeded in doing so only to a limited degree. Although not significantly different, the average energy gain of $8083.7 \mathrm{~kJ}_{\text {trip }}{ }^{-1}$ was still considerably lower than at Puñihuil (18566 kJ trip $\left.{ }^{-1}\right)$. In combination with the higher overall energetic costs per trip, this resulted in an average GFE of 0.94, which was significantly lower than 4.61 at Puñihuil.

A GFE of 4.61 is relatively high. In other species lower efficiencies were found, e.g. 1.55 in Adélie penguins Pygoscelis adeliae (Chappell et al. 1993) and 2.1 in African penguins Spheniscus demersus (Nagy et al. 1984). However, in male and female great cormorants Phalacrocorax carbo carbo GFEs of 3.25 and 3.46, respectively, were recorded (Grémillet 1997). These high GFEs were explained by the cormorants foraging in areas with very high prey availability, which yielded CPUEs of 15.2 and $9.0 \mathrm{~g} \mathrm{~min}^{-1}$ under water for males and females, respectively (Grémillet 1997). This value is similar to the CPUE of $10.0 \mathrm{~g} \mathrm{~min}^{-1}$ at Puñihuil. Thus, the GFEs determined at Puñihuil are not unusually high, but can be explained by a very favourable prey situation at this colony. In turn, the low GFEs at Pan de Azúcar reflect poor prey availability at the site, as indicated by oceanographic conditions.

\section{Effects on chick growth}

At Pan de Azúcar, the chick growth rates were about a third lower than at Puñihuil. A variety of parameters can negatively affect growth rates of chicks, such as infestation by parasites (Brown \& Brown 1986) or high ambient temperature (U. Kubetzki pers. comm.). A major factor, however, is insufficient supply of energy (e.g. Furness \& Monaghan 1987, Schreiber \& Burger 2001 for an overview).

Chick parasite loads were not specifically investigated, but seemed to be equally variable at both colonies. Ambient temperatures are unlikely to have caused differing growth rates, since at both colonies the majority of the nests were in caves and crevices that buffer changes in ambient temperature. The smaller growth rates at Pan de Azúcar can most probably be attributed to a poorer food supply. Meal size is likely to have been smaller than at Puñihuil due to lower GFEs, and, additionally, frequency of food delivery to the chicks was lower due to longer foraging trips, which was similarly observed in Adélie penguins (Takahashi et al. 2003).

\section{Gross foraging efficiency and chick survival}

The reproductive success at Pan de Azúcar was 0.33 fledglings nest ${ }^{-1}$. This was significantly lower than at Puñihuil, where 0.81 chicks fledged per nest. Since the hatching success at Pan de Azúcar (0.42 chicks egg ${ }^{-1}$, 25 chicks in 30 nests, see 'Materials and methods') was as high as at Puñihuil $\left(0.41\right.$ chicks egg $^{-1}, 39$ chicks in 48 nests), the difference in reproductive success must be due to differences in chick survival, which was significantly lower at Pan de Azúcar (40 vs. $100 \%$ at Puñihuil).

Due to the methodology of checking nests every 8 to $11 \mathrm{~d}$, the fate of disappeared chicks is unknown. Predation can have a considerable effect on chick mortality (e.g. Lack 1954, Ricklefs 1969, Nilsson 1984). Within the framework of a study on chick behaviour at the nest, 10 nests at Pan de Azúcar and 6 at Puñihuil were monitored continuously for 2 wk with small video cameras. At none of them was predation observed (J. C. Hennicke unpubl. data).

Food supply also influences chick survival. A foraging penguin has to attribute prey to itself and to the chicks: it is facing a trade-off between survival/future reproduction and current reproduction (Stearns 1992, Daan \& Tinbergen 1997). For long-lived seabirds reproductive seasons are potentially numerous (Furness \& Monaghan 1987). At a certain point under given conditions, it can be adaptive for an adult to give up breeding and to invest in its own survival, hence, in 
future reproduction. This point has been selected for during the evolution of a species, yet it varies between individuals (Stearns 1992, Daan \& Tinbergen 1997).

At Pan de Azúcar, the GFE was $<1$. This means that during the foraging trips more energy was spent than gained. To a certain degree the animal can compensate for the deficit by using body reserves such as fat (Culik 1995), and weight loss during foraging trips is not unusual in seabirds (e.g. Watanuki et al. 1993, Culik 1994, Weimerskirch et al. 1997, Ainley et al. 1998). Over long periods, however, GFEs <1 clearly cannot be sustained and breeding should be given up. At Pan de Azúcar, chick survival of $40 \%$ corresponds to a GFE of 1.08 (40\% of GFEs were above this value when fitting a polynomial function, $y=-0.02 x^{2}+0.18 x$ -0.05 , to the distribution of the determined GFE values). This GFE threshold should have been reached by foraging adults to successfully raise chicks. In contrast, at Puñihuil, prey availability was high enough to sustain adults and their chicks, and, hence, chick survival was significantly higher than at Pan de Azúcar.

As ecological conditions influencing GFE and energetic demands of chicks vary during breeding season, GFE thresholds for successful chick rearing will also change over the course of the breeding season. Further studies on threshold GFEs would not only increase our understanding of foraging strategies and reproductive decisions in seabirds, but also contribute to effective conservation by forecasting reproductive success of seabirds under natural and anthropogenically altered environmental conditions, such as El Niño and overfishing.

Acknowledgements. This work was made possible through a grant by the Deutsche Forschungsgemeinschaft, Bonn, Germany, to B.M.C. The Subsecretaria de Pesca (SERNAP), the Corporación Nacional Forestal (CONAF), Copiapo, III region, and Puerto Montt, X region, and the Fundación Otway, Puerto Montt, issued permits to work at the penguin colonies and helped with logistics. We thank D. Adelung and R. Wilson (Institut für Meereskunde) and H. George (Fundación Otway) for their support, and the rangers and Rodrigo at Pan de Azúcar, the fishermen at Puñihuil and W. Günther, G. and W. Knauf, J. Kozerka, I. Söhle, J. Valenzuela and A. Wanner for their help in the field. All experiments were carried out under licence and in accordance with the principles and guidelines of the German and Chilean laws on animal welfare.

\section{LITERATURE CITED}

Ainley DG, Wilson RP, Barton KJ, Ballard G, Nur N, Karl B (1998) Diet and foraging effort of Adélie penguins in relation to pack-ice conditions in the southern Ross Sea. Polar Biol 20:311-319

Arntz WE, Fahrbach E (1991) El Niño-Klimaexperiment der Natur. Birkhäuser Verlag, Basel

Arntz WE, Pearcy WG, Trillmich F (1991) Biological consequences of the 1982-83 El Niño in the eastern Pacific. In:
Trillmich F, Ono KA (eds) Pinnipeds and El Niño: responses to environmental stress. Springer Verlag, Heidelberg, p 22-42

Bannasch R, Wilson RP, Culik BM (1994) Hydrodynamic aspects of design and attachment of a back-mounted device in penguins. J Exp Biol 194:83-96

Brown CR, Brown MB (1986) Ectoparasitism as a cost of coloniality in cliff swallows (Hirundo pyrrhonota). Ecology 67: 1206-1218

Chappell MA, Shoemaker VH, Janes DN (1993) Energetics of foraging in breeding Adélie penguins. Ecology 74: $2450-2461$

Charrassin JB, Bost CA, Pütz K, Lage J, Dahier T, Zorn T, Le Maho Y (1998) Foraging strategies of incubating and brooding king penguins Aptenodytes patagonicus. Oecologia 114:194-201

Colling A (2001) Ocean circulation, 2nd edn, prepared by an Open University Course Team. Butterworth-Heinemann, Oxford, in association with the Open University, Walton Hall, Milton Keynes

Croxall JP, Davis RW, O'Connell MJ (1988) Diving patterns in relation to diet of gentoo and macaroni penguins at South Georgia. Condor 90:157-167

Culik BM (1994) Energy requirements of Pygoscelis penguins: a synopsis. Rep Polar Res 150

Culik BM (1995) Energy expenditure of Adélie penguins. In: Dann P, Normann I, Reilly P (eds) Penguins: ecology and management. Surrey Beatty \& Sons, Chipping Norton, p 177-195

Culik BM (2001) Finding food in the open ocean: foraging strategies in Humboldt penguins. Zoology 104:327-338

Culik BM, Wilson RP (1991a) Energetics of under-water swimming in Adélie penguins (Pygoscelis adeliae). J Comp Physiol B 161:285-291

Culik BM, Wilson RP (1991b) Swimming energetics and performance of instrumented Adélie penguins (Pygoscelis adeliae). J Exp Biol 158:355-368

Culik BM, Bannasch R, Wilson RP (1994a) External devices on penguins: how important is shape? Mar Biol 118: 353-357

Culik BM, Bannasch R, Wilson RP (1994b) Underwater swimming at low energetic costs by Pygoscelis penguins. J Exp Biol 197:65-78

Culik BM, Hennicke J, Martin T (2000) Humboldt penguins out-manoevering El Niño. J Exp Biol 203:2311-2322

Daan S, Tinbergen JM (1997) Adaptions of life histories. In: Krebs JR, Davies NB (eds) Behavioural ecology: an evolutionary approach, 4th edn. Blackwell Science, London, p 311-333

Furness RW, Monaghan P (1987) Seabird ecology. Chapman \& Hall, New York

Garthe S, Grémillet D, Furness RW (1999) At-sea activity and foraging efficiency in chick-rearing northern gannets (Sula bassana): a case study in Shetland. Mar Ecol Prog Ser 185:93-99

Grémillet D (1997) Catch per unit effort, foraging efficiency, and parental investment in breeding great cormorants (Phalacrocorax carbo carbo). ICES J Mar Sci 54:635-644

Grémillet D, Plös AL (1994) The use of stomach temperature records for the calculation of daily food intake in cormorants. J Exp Biol 189:105-115

Guerra C (1992) Efectos de la nidificación estival/inerval, sobre parámetros seleccionados de la historia de vida del pingüino de Humboldt Spheniscus humboldti. Informe Proyecto FONDECYT. 90-0599. Universidad de Antofagasta, Antofagasta

Herling C (2001) Zusammensetzung und Energiegehalt der 
Beuteorganismen chilenischer Pinguine. MSc thesis, University of Kiel

Herling C, Culik BM, Hennicke JC (2005) The diet of the Humboldt penguin Spheniscus humboldti in northern and southern Chile. Mar Biol 147(1):13-25

Hunt GL Jr, Schneider DC (1987) Scale-dependent processes in the physical and biological environment of marine birds. In: Croxall JP (ed) Seabirds: feeding biology and role in marine ecosystems. Cambridge Universitiy Press, Cambridge, $\mathrm{p} 7-41$

Kerr RA (1999) Big El Niños ride the back of slower climate change. Science 283:1108-1109

Kooyman GL (1989) Diverse divers. Springer Verlag, Berlin

Lack D (1954) The natural regulation of animal numbers. Clarendon Press, Oxford

Lalli CM, Parsons TR (1997) Biological oceanography, an introduction, 2nd edn. Butterworth-Heinemann, Oxford

Luna-Jorquera G (1996) Balancing the energy budget for a warm-blooded bird in a hot desert and cold seas: the case of the Humboldt penguin. $\mathrm{PhD}$ thesis, University of Kiel

Luna-Jorquera G, Culik BM (1999) Diving behaviour of Humboldt penguins Spheniscus humboldti in nothern Chile. Mar Ornithol 27:67-76

Luna-Jorquera G, Culik BM (2000) Metabolic rates of swimming Humboldt penguins. Mar Ecol Prog Ser 203:301-309

Luna-Jorquera G, Culik BM, Aguilar RE (1996) Capturing Humboldt penguins Spheniscus humboldti with the use of an anaesthetic. Mar Ornithol 24:47-50

McPhaden MJ (1999a) Genesis and evolution of the 1997-98 El Niño. Science 283:950-954

McPhaden MJ (1999b) The child prodigy of 1997-98. Nature 398:559-562

Morrison ML, Ralph CJ, Verner J, Jehl JR (1990) Avian foraging: theory, methodology, and applications. Stud Avian Biol 13:1-515

Nagy KA, Siegfried WR, Wilson RP (1984) Energy utilization by free-ranging jackass penguins, Spheniscus demersus. Ecology 65:1648-1655

Nilsson SG (1984) The evolution of nest-site selection among hole-nesting birds: the importance of nest predation and competition. Ornis Scand 15:167-175

Peters G (1997) Die Regulation der Verdauungsprozesse bei Pinguinen (Spheniscidae). PhD thesis, University of Kiel

Quinn WH, Zopf DO, Short KS, Kuo Yang RTW (1978) Historical trends and statistics of the Southern Oscillation, El Niño, and Indonesian droughts. Fish Bull (Wash DC) 76: 663-678

Radl A, Culik BM (1999) Foraging behaviour and reproductive success in Magellanic penguins (Spheniscus magellanicus): a comparative study of two colonies in southern Chile. Mar Biol 133:381-393

Ricklefs RE (1969) An analysis of nesting mortality in birds. Smithson Contrib Zool 9:1-48

Ropert-Coudert Y, Bost CA, Handrich Y, Bevan RM, Butler PJ, Woakes AJ, Le Maho Y (2000) Impact of externally attached loggers on the diving behaviour of the king penguin. Physiol Biochem Zool 73(4):438-445

Ryther JH (1969) Photosynthesis and fish reproduction in the sea. Science 166:72-73

Schmitt-Nielsen K (1990) Animal physiology: adaptation and environment. Cambridge Universtiy Press, Cambridge

Schreiber EA, Burger J (2001) Biology of marine birds. CRC Press, Boca Raton, FL

SERNAP (Servicio Nacional de Pesca) (1997) Anuario estadís- tico de pesca, 1996. SERNAP, Ministerio de Economia, Fomento y Reconstruccion, Valparaiso

SERNAP (Servicio Nacional de Pesca) (1999) Anuario estadístico de pesca, 1998. SERNAP, Ministerio de Economia, Fomento y Reconstruccion, Valparaiso

Simeone A, Schlatter RP (1998) Threats to a mixed-species colony of Spheniscus penguins in southern Chile. Colon Waterbirds 21(3):418-421

Stearns SC (1992) The evolution of life histories. Oxford University Press, Oxford

Takahashi A, Watanuki Y, Sato K, Kato A, Arai N, Nishikawa J, Naito Y (2003) Parental foraging effort and offspring growth in Adélie penguins: does working hard improve reporductive success? Funct Ecol 17:590-597

Tasker ML, Furness RW (1996) Estimation of food consumption by seabirds in the North Sea. ICES Coop Res Rep 216: $6-42$

Taylor SS, Leonard ML, Boness DJ, Majluf P (2001) Foraging trip durations increases for Humboldt penguins tagged with recording devices. J Avian Biol 32:369-372

Watanuki Y, Kato A, Mori Y, Naito Y (1993) Diving performance of Adélie penguins in relation to food availability in fast sea-ice areas: comparison between years. J Anim Ecol 62:634-646

Watanuki Y, Kato A, Naito Y, Robertson G, Robinson S (1997) Diving and foraging behaviour of Adélie penguins in areas with and without fast ice. Polar Biol 17:296-304

Weathers WW, Sullivan KA (1991) Foraging efficiency of parent Juncos and their young. Condor 93:346-353

Weimerskirch H, Cherel Y, Cuenot-Chaillet F, Ridoux V (1997) Alternative foraging strategies and resource allocation by male and female wandering albatrosses. Ecology 78(7):2051-2063

Williams TD (1995) The penguins Spheniscidae. Bird families of the world. Oxford University Press, Oxford

Wilson RP (1984) An improved stomach pump for penguins and other seabirds. J Field Ornith 55(1):109-112

Wilson RP (1995) Foraging ecology. In: Williams TD (ed) The penguins Spheniscidae. Bird families of the world. Oxford University Press, Oxford, p 81-106

Wilson RP, Pütz K, Bost CA, Culik BM, Bannasch R, Reins T, Adelung D (1993) Diel dive depth in penguins in relation to diel vertical migration of prey: whose dinner at candlelight? Mar Ecol Prog Ser 94:101-104

Wilson RP, Duffy DC, Wilson MP, Araya B (1995a) The ecology of species replacement of Humboldt and Magellanic penguins in Chile. Gerfaut 85:49-61

Wilson RP, Pütz K, Grémillet D, Culik BM and 5 others (1995b) Reliability of stomach temperature changes in determining feeding characteristics of seabirds. J Exp Biol 198: $1115-1135$

Wilson RP, Pütz K, Peters G, Culik BM, Scolaro JA, Charrassin JB, Ropert-Coudert Y (1997) Long-term attachment of transmitting and recording devices to penguins and other seabirds. Wildl Soc Bull 25(1):101-106

Wilson RP, Peters G, Regel J, Grémillet D, Pütz K, Kierspel M, Weimerskirch H, Cooper J (1998) Short retention times of stomach temperature loggers in free-living seabirds: is there hope in the spring? Mar Biol 130:559-566

Ydenberg RC, Clark CW (1989) Aerobiosis and anaerobiosis during diving by western Grebes: an optimal foraging approach. J Theor Biol 139:437-449

Zavalaga C, Paredes R (1997) Humboldt penguins at Punta San Juan, Peru. Penguin Conserv 10(1):6-8 